\title{
The Economics of Conflict and Peace
}

Dominic Rohner, University of Lausanne ${ }^{1}$

April 24, 2017

\section{Introduction: Taking stock of existing key findings}

To know where we are going, we need to know where we stand and where we come from. I will thus first describe in the current introduction section 1 the main existing results in the literature on the economics of conflict and peace. ${ }^{2}$ After this, I will describe in section 2 what the main cutting-edge lines of research and emerging trends are, and will then in section 3 offer some conclusions and formulate-somewhat more speculative- views on which turn the literature may be taking in the coming years.

\section{Costs and consequences of conflict}

The first question to always ask before plunging into a research topic is whether it is relevant and important enough for international scholars to study it. Thus, we shall start below by summarizing why conflicts are a major problem requiring our attention.

\section{Human lives lost}

The foremost cost of conflict is, of course, in terms of human lives. Between 1945 and 1999 an estimated 3.3 million people got killed in 25 interstate wars, and 16.2 million direct fatalities took place in 127 civil wars (Fearon and Laitin, 2003). Diseases and other indirect effects more than double this death toll (Ghobarah et al., 2003). Much violence also occurs away from the battlefield, when armed troops turn their weapons against defenseless civilians. Since World War II some 50 episodes of mass killings have led to between 12 and 25 million civilian casualties (Political Instability Task Force, 2010), involving in many cases the governments attacking political or ethnic minority groups among the

\footnotetext{
${ }^{1}$ Acknowledgements: Dominic Rohner gratefully acknowledges financial support from the ERC Starting Grant 677595 "Policies for Peace".

${ }^{2}$ A survey of the existing key findings in the literature is provided in Rohner (2016), on which Section 1 of the current text draws on.
} 
population, as for example during the infamous Stalinist purges, the massacres committed by the Red Khmer in Cambodia, and, more recently, the ethnic cleansing in Sudan's Darfur region.

\section{Monetary costs}

Also the economic costs of conflict are large: Civil wars tend to reduce growth by 2.3 percent per year, so the average civil war which lasts about 7 years reduces GDP by about 15 percent (Collier, 2007).

Taking into account the direct and indirect costs of a civil war, as well as spillovers to neighboring states, Collier (2007) estimates the cost of a typical civil war at around \$ 64 billion. Not only major civil wars, such as the Second Congo War from 1998-2003 in the Democratic Republic of Congo (DRC) killing millions, have a major impact on the economy. Even comparatively mild forms of civil wars and terrorism, such as for example the conflicts in the Basque Country and in Northern Ireland leave crucial footprints on the local economy. When estimating the costs of terrorism in the Basque country between 1955 and 1995 by comparing it to a weighted average of comparable Spanish regions, Abadie and Gardeazabal (2003) show that Basque GDP would be $10 \%$ higher today if ETA's armed struggle had not happened.

\section{Other consequences of war}

It is of course important to bear in mind that the costs of conflict are not just limited to death tolls and economic losses. There is substantial evidence that conflict harms physical and mental health (see e.g. Barenbaum et al., 2004) and that it drives down schooling and long-run educational outcomes (see e.g. Shemyakina, 2011). Finally, warfare also affects trust, political participation, and future crime behavior in the aftermath of conflict. There is still a lively debate on the societal impact of war, with some papers finding that conflict drives down inter-group trust (Rohner et al., 2013), and makes war victims more likely to engage in crime or conflict later in life (Couttenier et al., 2016; Rohner et al., 2013b), while other papers conclude that conflict boosts local collective action (see the survey of Bauer et al., 2016).

\section{Causes of conflict}

\section{Ethnic strive}

Recent research shows that ethnic and religious diversity are a main driver of conflict. Economists have early on started to look for measures that capture the importance of ethnic diversity. While also ethnic fractionalization (which is increasing in the number of groups) has been found to correlate positively with conflict, the strongest effect has been found from ethnic polarization (which is largest in a bipolar distribution of two similarly sized groups facing each other) (see Montalvo and Reynal-Querol, 2005; Rohner, 2011; Esteban et al., 2012).

\section{Resource curse}

Another empirical regularity that has received a lot of attention in recent years is that many resourcerich countries are poor (Fearon and Laitin, 2003; Collier and Hoeffler, 2004). This at first sight paradoxical correlation between natural resource abundance and poverty has been dubbed the "resource curse". The channels that fuel the conflict-inducing impact of Mother Nature's riches are manifold as well. First, and most obviously, it becomes more lucrative to conquer a place with more valuable resources to capture (which has been found by many papers, e.g. Lei and Michaels, 2014). 
Another important reason why oil and other resources can be dangerous for peace is that often they are not evenly distributed in a given country. It is hence not only the total amount of natural resources that matters but how they are distributed over the territory (Morelli and Rohner, 2015). The most dangerous situation is when most natural resource fields are concentrated in the ethnic homelands of ethnic minority groups that would be economically better off from splitting from the rest of the country. Asymmetries in resource holdings have also been drivers of various militarized interstate disputes in the past decades (Caselli et al., 2015).

Besides fueling the risk of civil and interstate wars between armed groups, oil has also been found to make massacres of civilians more lucrative for cynical governments (Esteban et al., 2015). The government's terrifying trade-off is as follows: When reducing the size of a minority group (by mass killings or expulsion), the government can increase its share of national wealth to appropriate, but at the same time the size of the economy shrinks (as less people produce less). When most of the national economy relies on productive labor, the output is reduced so substantially after massacres that they typically do not pay off for the government. In contrast, the extraction of natural resources requires only relatively little local labor, hence in states with natural resource extraction accounting for a large share of GDP, national output shrinks relatively less after massacres, making the latter relatively more lucrative for cynical governments.

The bad news continues, as natural resource abundance does not only increase the likelihood of political violence taking place, but also its diffusion and length. According to the "feasibility hypothesis", resource money constitutes not only the "prize" or "pie" to appropriate, but also helps paying for the fighting while it happens. In the absence of perfect capital markets, looting of resource rents allows rebels to fund their cause, expand their zone of activity, and spread violence over a greater area and for a longer time. Recent evidence in line with this view is e.g. provided by the study of the conflict-inducing effect of mineral wealth by Berman et al. (2017).

Besides these direct effects, there are also several indirect ways in which natural resources boost the conflict risk by undermining the state and the economy. To start with, "rentier states" have less of a need to build up fiscal capacity and a tax collection apparatus than other states, and hence they tend to become weaker states with less state capacity and less efficient bureaucracies (Besley and Persson, 2011). Further, by its very nature, natural resource exploitation often requires very substantial amounts of capital. While increased mineral and oil and gas prices lead to a boom in the capital-intensive extraction industry, other, more labor-intensive sectors suffer from less capital, which leads to a drop in wages, and hence reduced opportunity costs of fighting, as shown by Dal Bo and Dal Bo (2011) and Dube and Vargas (2013).

\section{Plight of poverty}

For many years, political scientists and economists have documented the positive correlation between poverty and fighting. More recently, making use of rain fall deviations from the mean, a series of papers have shown that a rise in poverty (i.e. due to drought driving down agricultural yields) fuels the risk of conflict (see e.g. Miguel et al., 2004). 


\section{Cutting edge and emerging trends}

After having singled out above some major consequences and causes of conflict established in the existing literature, I shall now below focus on a series of emerging trends.

\section{Addressing statistical biases: Disaggregation and Creation of New Data}

The trend of focusing on putting together novel kinds of data has already started about ten years ago. While the pioneering work of Fearon and Laitin (2003) and Collier and Hoeffler (2004) have highlighted various correlates of conflict, many of the existing variables at that point of time were time invariant, such as e.g. ethnic diversity measures, or the shares of land covered by mountainous terrain, or did not vary much over time. This means that much of the statistical variation has lied in the cross-section of countries. The statistical pitfall of this is the concern of potential omitted variable bias and unobserved heterogeneity, as it is close to impossible to control for all dimensions in which countries differ. Further, in many countries conflict are localized in some part, e.g. the Niger delta in Nigeria or FARC-controlled areas in Colombia. Hence, by carrying out an analysis at the country level, much statistical noise is added.

The quest of causal identification and for reducing unobserved heterogeneity has led scholars to consider a variety of avenues. While a small number of papers have focused on exploiting exogenous variation at the country level (see e.g. Miguel et al., 2004, making use of variation in country-level rain fall), many papers in recent years have focused on exploiting within-country variation. Given that nationwide institutions are identical within countries and that overall unobserved heterogeneity is typically smaller for within-country studies in a variety of dimensions, focusing on different regions of a given country reduces the risk of "comparing apples with pears". Recent articles using geo-graphically disaggregated data to explain the causes and impact of conflict include, among many others, Cederman et al. (2009), Cassar et al. (2013), Dube and Vargas (2013), La Ferrara and Harari (2014), Michalopoulos and Papaioannou (2017), Berman et al. (2017), and Mueller et al. (2017).

Working with disaggregate data does not only serve the purpose of reducing unobserved heterogeneity, but at the same time allows to create new sets of variables that previously have not been available. New variables of course also means new ways of testing existing or new theories. For example, Michalopoulos and Papaioannou (2017) have created a novel measure of partitioned ethnic groups, and La Ferrara and Harari (2014) have computed agriculture-relevant shocks, taking into account the local crop coverage and growing seasons. Such variables would have been impossible to put together without drawing on disaggregate data.

\section{Letting Theory Guide the Empirics}

In recent years there have been several papers trying to create a tight link between a new theory and novel evidence testing the theory. To name a few contributions, Besley and Persson (2011) have built a formal model of how a variety of political and economic variables related to state capacity affect the risk of conflict and have presented empirical findings in line with the key predictions of the model. Similarly, also Dube and Vargas (2013) start from a theoretical model predicting contrasting effects of price shocks 
depending on whether they occur in labor-or capital-intensive sectors and test this using Colombian data to assess the impact of price shocks for labor-intensive commodities (coffee) versus shocks to capital-intensive sectors (oil). Another example of research linking theory to empirics is Caselli et al. (2015) who build a model of how distance of oil wells from international borders affect the risk of interstate conflicts, and test the predictions of the model, putting together novel data on oil location for all county pairs around the world.

Some papers also focus on estimating directly the coefficients of a structural model (i.e. they start from a mathematical model and make use of the empirical data to compute the values of the variables of the model). For example, König et al. (2017) integrate network spillovers into a contest model, allowing predicting the impact of increased fighting effort of allies and enemies. These spillover parameters are then structurally estimated, exploiting exogenous variation in rainfall. Similarly, Mueller et al. (2017) build a model of how distance to potential targets affects recruiting efforts and attacks by sectarian paramilitary groups, and then estimate the spatial weight coefficients of the model using disaggregate data from Northern Ireland. They conclude that there are indeed large transport costs of violence and that changing distances between conflict parties can explain a large drop in violence.

\section{Being Policy Relevant}

Up to recently, many of the papers in the literature have focused on drivers of conflict that are easily measurable and relatively exogenous, such as for example natural resource abundance, ethnic polarization, and exogenous income variations (as discussed above). Policy and institutions of course also matter heavily for conflict. However, policy-related determinants of conflict are by their very nature harder to measure and plagued by endogeneity problems. Put bluntly, while variations in, say, rain are to a large extent driven by exogenous factors linked to mother nature, variations in policies like, say, education or health spending, are to a large extent the product of endogenous human choices, and it is harder to find some random variation allowing a clean statistical identification of causality. This may be one of the reasons why the role of policies and institutions for preventing conflict and favoring successful post-war reconstruction has -up to recently-- received far less attention in the literature. In recent years, however, there has been a growing interest in being able to study policy-relevant questions.

First of all, the impact of institutions has received some attention in recent years. Most empirical papers have found democracy to be a double-edged knife, at the same time reducing grievances against the state, but enabling potential opponents to more easily coordinate anti-government action. In particular, there is evidence for an "inverted U-shape", i.e. "anocracies" with intermediate democracy scores fare worst (Hegre et al., 2001; Fearon and Laitin, 2003). Collier and Rohner (2008) find that in poor countries the conflict-inducing effects of democracy dominate, while in rich countries the peace-promoting channels dominate. While democracy remains very attractive for all countries, the fragility of poor democracies calls for support by the international community to alleviate poverty and increase the opportunity cost of fighting. Moreover, Besley and Persson (2011) have emphasized the role of institutional constraints for peace by dealing with economic shocks. Power-sharing has received increasing attention recently. Cederman et al. (2013) show that ethnic groups included in government 
show less propensity to engage in insurgency, and Mueller and Rohner (2017) find that power-sharing reduces the scope for sectarian violence, using novel data from Northern Ireland.

Not just institutions but also specific policies have received a resurging interest, with for example Berman et al. (2017) showing that transparency initiatives for declaring mineral origins as well as good corporate social responsibility of mining firms can curb conflict. König et al. (2017) have found that while arms embargoes may in many cases not be sufficient to drive down fighting, bilateral reconciliation and trying to demobilize keyplayer groups in the network can be promising in pacification. Nunn and Qian (2015) find that US food aid had in many cases rather a neutral or harmful than positive impact on pacification, while Dal Bó and Dal Bó (2011) have shown that subsidizing productive labor can play a key role at promoting peace. Couttenier et al. (2016) find that the negative consequences of war exposure in terms of future violent behavior can be countered by promoting labor market access and integration in the society.

Very recently, there is also a trend towards using randomized control trials (RCT) ${ }^{3}$ to study policy relevant interventions. Cilliers et al. (2016) have treated some village with reconciliation meetings in a post-conflict context while not holding such meeting in the control group. They have found that such meetings indeed increase social capital but decrease individual well-being. Focusing similalry on postconflict reconstruction, Annan and Blattman (2016) study the reintegration of "high-risk men" (many of whome being former combatants) in a post-conflict context.

\section{Conclusions and Forecast}

When children grow up they become more mature. The same can be seen in economic literatures on particular topics and fields. Trade economics and labor economics, for example, have become ever more sophisticated over the last few decades, pushing further the causal identification, reducing statistical biases, using more disaggregate data, allowing a tighter link between theory and empirics and studying in an as clean as possible way the impact of particular policies. Conflict and peace economics is going down the same route. While it is a younger literature -at least in economics- it is catching up rapidly in terms of methodological sophistication and is in many aspects even leap-frogging - going beyond the gold standards of other literatures, for example as far as the use of geo-referenced data is concerned.

While in terms of causal identification the conflict and peace literature has already reached a high level of sophistication, the main catching up needed is in terms of being able to give useful advice to policymakers as far as the evaluation of particular policies is concerned. So far, we do not know enough on what mix of policies can curb conflict and it is in this dimension where I expect the biggest progress in the coming years. Of course, one needs to bear in mind that studying policies is particularly hard as far as conflict is concerned, given that the stakes are so high, and experimenting with policies is in many cases not possible. Still, RCTs can be an option when it comes to things such as reconciliation initiatives,

\footnotetext{
${ }^{3}$ Like in medicine, in a RCT the pool of subjects or villages is randomly allocated between treatment and control group, allowing to compare, say, a village subject to some policy with another, very comparable village that is for random reasons not subject to this policy.
} 
reintegration coaching, further professional training for former combatants and when the interest from potential participants is much larger than the available budget. In this case, randomization of access may be ethically defendable and allows a clean impact evaluation. We still know far too little about how to successfully promote post-conflict reconstruction, so studies on this are very much encouraged.

A good alternative to RCTs is also to exploit existing random variation in policies. When for example a knife-edge electoral victory close to the $50 \%$ votes threshold decides on the adoption or not of a given policy or when a given policy reform is for exogenous (e.g. budgetary reasons) not implemented in all parts of a country at the same time, then again this allows for relatively clean statistical identification of causality. In my opinion it is very worthwhile to focus much more on searching for such quasi-natural experiments to study the impact of policies on conflict.

While studying conflict and peace is hard, it is well worth the effort, as also the rewards of reducing somewhat the human suffering from fighting would be extremely high.

\section{References:}

Abadie, Alberto, and Javier Gardeazabal, 2003, "The Economic Costs of Conflict: A Case Study of the Basque Country", American Economic Review 93: 113-132.

Annan, Jeannie, and Christopher Blattman, 2016, "Can employment reduce lawlessness and rebellion? A field experiment with high-risk men in a fragile state", forthcoming, American Political Science Review.

Barenbaum, Joshua, Vladislav Ruchkin, and Mary Schwab-Stone, 2004, "The psychological aspects of children exposed to war: practice and policy initiatives", Journal of Child Psychology and Psychiatry 45: 41-62.

Bauer, Michal, Christopher Blattman, Julie Chytilová, Joseph Henrich, Edward Miguel, and Tamar Mitts, 2016, „Can War Foster Cooperation?”, Journal of Economic Perspectives 30: 249-274.

Berman, Nicolas, Mathieu Couttenier, Dominic Rohner and Mathias Thoenig, 2017, "This mine is mine! How minerals fuel conflicts in Africa", forthcoming, American Economic Review.

Besley, Timothy, and Torsten Persson, 2011, Pillars of Prosperity, Princeton NJ: Princeton University Press.

Caselli, Francesco, Massimo Morelli, and Dominic Rohner, 2015, "The Geography of Inter-State Resource Wars", Quarterly Journal of Economics 130: 267-315.

Cassar, Alessandra, Pauline Grosjean, and Sam Whitt, 2013, "Legacies of violence: trust and market development." Journal of Economic Growth 18: 285-318.

Cederman, Lars-Erik, Halvard Buhaug and Jan Ketil Rod, 2009, "Ethno-Nationalist Dyads and Civil War : A GIS-Based Analysis", Journal of Conflict Resolution 53: 496-525. 
Cederman, Lars-Erik, Kristian Skrede Gleditsch and Halvard Buhaug, 2013, Inequality, Grievances and Civil War, Cambridge: Cambridge University Press.

Cilliers, Jacobus, Oeindrila Dube and Bilal Siddiqi, 2016, "Reconciling after civil conflict increases social capital but decreases individual well-being" 352: 787-794.

Collier, Paul, 2007, The Bottom Billion: Why the Poorest Countries Are Failing and What Can Be Done About It, Oxford, Oxford University Press.

Collier, Paul and Anke Hoeffler, 2004, "Greed and Grievance in Civil War", Oxford Economic Papers 56: 563-95.

Collier, Paul, and Dominic Rohner, 2008, "Democracy, Development, and Conflict", Journal of the European Economic Association 6: 531-40.

Couttenier, Mathieu, Veronica Preotu, Dominic Rohner and Mathias Thoenig, 2016, "The Violent Legacy of Victimization: Post-Conflict Evidence on Asylum Seekers, Crimes and Public Policy in Switzerland", CEPR Discussion Paper 11079.

Dal Bó, Ernesto and Pedro Dal Bó, 2011, "Workers, Warriors, and Criminals: Social Conflict in General Equilibrium", Journal of the European Economic Association 9: 646-677.

Dube, Oendrila, and Juan Vargas, 2013, "Commodity Price Shocks and Civil Conflict: Evidence from Colombia", Review of Economics Studies 80: 1384-1421.

Esteban, Joan, Laura Mayoral, and Debraj Ray, 2012, "Ethnicity and Conflict: An Empirical Investigation," American Economic Review 102: 1310-1342.

Esteban, Joan, Massimo Morelli, and Dominic Rohner, 2015, "Strategic Mass Killings", Journal of Political Economy 123: 1087-1132.

Fearon, James and David Laitin, 2003, "Ethnicity, Insurgency, and Civil War", American Political Science Review 97: 75-90.

Ghobarah, Hazen, Paul Huth and Bruce Russett. 2003. Civil Wars Kill and Maim People-Long After the Shooting Stops, American Political Science Review 97: 189-202.

Hegre, Havard, Tanja Ellingsen, Scott Gates and Nils Petter Gleditsch, 2001, "Toward a Democratic Civil Peace? Democracy, Political Change, and Civil War, 1816-1992", American Political Science Review 95: 33-48.

König, Michael, Dominic Rohner, Mathias Thoenig, 2017, „Networks in Conflict: Theory and Evidence from the Great War of Africa", forthcoming, Econometrica.

La Ferrara, Eliana, and Mariaflavia Harari, 2014, "Conflict, Climate and Cells: A Disaggregated Analysis", mimeo, Bocconi University. 
Lei, Yu-Hsiang, and Guy Michaels, 2014, "Do Giant Oil Field Discoveries Fuel Internal Armed Conflicts?", Journal of Development Economics 110: 139-157.

Michalopoulos, Stelios, and Elias Papaioannou, 2017, "The Long-Run effects of the Scramble for Africa", forthcoming, American Economic Review.

Miguel Edward, Shanker Satyanath and Ernest Sergenti, 2004, "Economic Shocks and Civil Conflict: An Instrumental Variables Approach", Journal of Political Economy 112: 725-753.

Montalvo, José and Marta Reynal-Querol, 2005, "Ethnic Polarization, Potential Conflict, and Civil Wars," American Economic Review 95: 796-815.

Morelli, Massimo, and Dominic Rohner, 2015, "Resource Concentration and Civil Wars", Journal of Development Economics 117: 32-47.

Mueller, Hannes and Dominic Rohner, 2017, “Can Power-sharing Foster Peace? Evidence From Northern Ireland", working paper, IAE and University of Lausanne.

Mueller, Hannes, Dominic Rohner and David Schönholzer, 2017, "The Peace Dividend of Distance: Violence as Interaction Across Space", Working Paper, IAE, University of Lausanne and UC Berkeley.

Nunn, Nathan, and Nancy Qian, 2014, "US Food Aid and Civil Conflict", American Economic Review 104: 1630-1666.

Political Instability Task Force. 2010. "Genocides." Dataset, http://globalpolicy.gmu.edu/pitf/.

Rohner, Dominic, 2011, "Reputation, Group Structure and Social Tensions", Journal of Development Economics 96: 188-199.

Rohner, Dominic, 2016, "The Economics of Peace: Can "Swiss" Institutions Do the Job?", Working Paper, UBS Center Public Paper Nr. 5.

Rohner, Dominic, Mathias Thoenig, and Fabrizio Zilibotti, 2013, "Seeds of Distrust: Conflict in Uganda", Journal of Economic Growth 18: 217-252.

Rohner, Dominic, Mathias Thoenig, and Fabrizio Zilibotti, 2013b, "War Signals: A Theory of Trade, Trust and Conflict", Review of Economic Studies 80: 1114-1147.

Shemyakina, Olga, 2011, "The effect of armed conflict on accumulation of schooling: Results from Tajikistan", Journal of Development Economics 95: 186-200. 